\title{
SCRIITORI ROMANI DE EXPRESIE GERMANA DIN TRANSILVANIA (1890-1960)
}

\author{
ROMANIAN WRITERS IN GERMAN \\ FROM TRANSYLVANIA (1890-1960)
}

\section{Mihaela HRISTEA 1}

https://doi.org/10.52744/9786062613242.22

\begin{abstract}
Rezumat: Datorită poziției sale geografice față de țările occidentale şi a specificului multicultural, Transilvania a fost, grație grupurilor etnice de români, germani, maghiari şi alte naționalități care au trăit aici, un promotor atât al influențelor occidentale, cât şi al valorilor culturale locale. Presa scrisă a fost mijlocul prin care aceste naționalități au avut posibilitatea să îşi păstreze limba, tradițiile, obiceiurile şi cultura. Astfel, în 1920, intelectualii români, germani şi maghiari au deschis noi orizonturi culturii, reuşind să depăşească barierele etnice tradiționale. Prin publicațiile lor au exprimat respect pentru pluralitate şi diversitate etnoculturală, toleranță religioasă şi şi-au afirmat propria identitate culturală şi națională. Prezenta lucrare intenționează să analizeze literatura etnică germană de la începutul secolului al XX-lea, care a fost tradusă parțial şi în limba română.
\end{abstract}

Cuvinte cheie: Scriitori Români; Expresie Germană; Transilvania; Presa scrisă

\begin{abstract}
Arising from its geographical position in relation to the Western countries and the multicultural specificity of this space, Transylvania was, due to the ethnic groups of Romanians, Germans, Hungarians, and other nationalities who lived there, a promoter of both Western influences and local cultural values. The print media was the means for these nationalities to preserve their language, traditions, customs and culture. Thus, in 1920, Romanian, German and Hungarian intellectuals opened new cultural horizons, managing to overcome traditional ethnic barriers. Through their publications, they expressed respect for plurality and ethnocultural diversity, religious tolerance, and asserted at the same time their own cultural and national identity. This study intends to survey the ethnic German literature at the beginning of the twentieth century that has also been partially translated into Romanian.
\end{abstract}

Keywords: Romanian Writers; German Expression; Transylvania; Media

${ }^{1}$ Lector univ. Dr., Universitatea Creştină Dimitrie Cantemir, mihaela.hristea@ucdc.ro 
Transilvania a fost, prin poziția către vest, dar şi prin specificul multicultural al acestui spațiu, datorită românilor, germanilor, maghiarilor şi altor naționalități care locuiau aici, o promotoare, atât a influențelor din Occident, cât şi a valorilor culturale autohtone.

Etniile conlocuitoare şi-au păstrat, atât limba, cât şi tradițiile, obiceiurile şi cultura, prin presa proprie.

În 1920, intelectualii români, germani şi maghiari au deschis noi orizonturi actului de cultură, reuşind să depăşească barierele etnice tradiționale. Prin publicațiile lor la revistele „Cultura”, „Erdélyi Helikon” şi „Klingsor”, ei au dat expresie respectului pentru pluralitate şi diversitate etnoculturală, toleranță religioasă şi şi-au afirmat propria identitate culturală şi națională.

Literatura de expresie germană a fost tradusă parțial şi în limba română. Saşii, cea mai numeroasă populație germană din România s-au stabilit în centrul țării unde şi-au construit un univers propriu. Purtători ai unor valori ale civilizației occidentale şi conştienți de superioritatea lor, ei şi-au construit în timp structuri care să păstreze statutul lor social şi politic.

Comunitatea germană din Transilvania a fost un model pentru celelalte etnii, impunându-se ca susținătoare a spiritului civilizațiilor europene. Saşii din Transilvania şi-au dorit mereu regăsirea propriei identități în contextul multicultural al spațiului în care trăiau. Minoritatea germană cunoaşte o înflorire pe plan cultural în primul rând după Primul Război Mondial, când a asistat împreună cu românii, maghiarii, evreii şi celelalte naționalități la înfăptuirea Marii Uniri din 1918.

Saşii au transmis din generație în generație tradițiile culturale proprii regiunii de proveniență având ca deziderat permanent, păstrarea limbii materne. În afară de o manifestare locală a tradițiilor şi folclorului lor, germanii s-au exprimat şi prin intermediul presei scrise.

În perioada interbelică, presa săsească a cunoscut cea mai înfloritoare perioadă. Atunci au apărut pentru prima dată până la patru cotidiene concomitent. Două reviste de cultură sunt cele mai cunoscute în spațiul germanofon, respectiv, „Ostland” şi „Klingsor”.

După 1918, saşii erau în număr de 254.00o, iar în 1930 s-au aflat în mijlocul României şi au constituit nucleul minorității germane (formate din 754.00o de locuitori). Periodicele saşilor ajungeau şi la ceilalți germani din România, fapt care a condus la creşterea tirajelor. Unele reviste, cum este cea intitulată „Das Ziel, Kultur und Satyre” (Țelul, cultura şi satira), continuată de „Das neue Ziel” (Noul țel) mobilizează colaboratori din toată România şi solidarizează autori de limba germană, atât din Banat şi Transilvania, cât şi din Bucovina sau Bucureşti, reuşind să transpună impulsuri ale expresionismului european în spaţiul 
românesc. Aceasta pregăteşte programul cultural pentru cea mai importantă revistă culturală transilvăneană, care se tipăreşte la Braşov în perioada interbelică, cu titlul „Klingsor”, care are drept scop popularizarea poeziei şi prozei în limba germană din Transilvania.

Lirica în limba germană de la sfârşitul secolului al XIX-lea şi până după Primul Război Mondial are pronunțate influențe ale naturalismului, impresionismului, jugendstilului şi neoromantismului. Dintre poeții care s-au remarcat înaintea de răscrucea dintre veacuri amintim pe: Michael Albert, Friedrich Krasser, Friedrich Wilhelm Schuster, Traugott Teusch, Regine Ziegler, Wilhelm Hermann şi Friedrich Rheindt.

În primele decenii ale secolului XX, poeții de expresie germană din Transilvania au continuat tradiția autohtonă scriind „lieduri” (cânturi). Dintre aceştia de remarcat sunt Franz Rheingt, Johann Lehrer, Wiegand Hermann şi Viktor Oredi.

Universul tematic este total diferit față de cel de la sfârşitul secolului al XIX-lea, predominând dragostea de patrie, popor şi gama variată de sentimente umane, în mod deosebit viața saşilor din Transilvania. Poeții germani scriu în special poezii de dragoste şi versuri în care preamăresc frumusețea naturii. Poemelor lor au fost publicate înainte de primul razboi mondial în revista „Die Karpaten” (Carpații). Această publicație a contribuit la popularizarea creaților lirice ale poeților germani care s-au afirmat la începutul secolului XX. Creația lirică a poeților din Transilvania a înregistrat o dezvoltare deosebită datorită contactelor permanente cu civilizația occidentală.

În ceea ce priveşte proza de expresie germană din această provincie românească, aceasta a reflectat realitățile istorice şi sociale ale vremii. Universul tematic al narațiunilor scriitorilor transilvăneni transpune realitatea cotidiană şi, în mod deosebit cea economică şi social-politică. S-a scris atât proză scurtă, respectiv nuvele, povestiri sau schițe, dar şi romane.

La sfârşitul secolului al XIX-lea remarcăm activitatea a doi prozatori germani: Gustav Seivert şi Josef Marlin. Aceştia au continuat tradiţia narațiunii germane din secolul al XIX-lea din Transilvania. Gustav Seivert a tipărit publicații având ca tematică istoria, în mod deosebit cea a Transilvaniei. Lucrarea sa cea mai importantă este „Cultur-historiche Novellen aus dem Siebenbürger Sachsenlande” (Nuvele cultural-istorice din țara saşilor transilvăneni). Joseph Marlin a scris de asemenea despre istoria saşilor din Transilvania. Nuvelele sale, publicate cu titlul „Geschichten des Ostens” (Povestiri de la Răsărit), au accente lirice.

Nuvela de expresie germană apărută la sfârşitul secolului al XIX-lea a cunoscut o etapă prosperă în perioada interbelică. Reprezentanții prozei de expresie germană din secolul al XX-lea sunt: Erwin Wittstock, Adolf Meschendörfer, Heinrich Zillich şi Oscar Walter Cisels. Universul tematic 
al operelor scriitorilor de mai sus reflectă în mare parte realitățile vieții din România. Ei s-au inspirat, atât din realitățile şi problemele minorității germane, cât şi din viața poporului român şi a altor naționalităţi din țara noastră.

Tendințele naturaliste sau realiste nu sunt agreate de minoritatea germană, deosebit de conservatoare în ceea ce priveşte gustul literar. Saşii citesc operele care prezintă realitatea cotidiană, omul în contextul locului natal, al spațiului din apropierea locuinței. Scriitori care au reflectat acest univers tematic sunt: Michael Königes, Hans Lienert, Erwin Wittstock, Otto Fritz Jickeli, Schuster Dutz, Bernhard Capesius, Stefan şi Wilhelm von Hannenheim.

Prozatorii care au descris evenimentele tragice şi consecinţele Primului Război Mondial au fost Emil Witting şi Erwin Wittstock. Primul publică în 1932 romanul „Hirtenfeuer” (Focul păstorilor), iar Erwin Wittstock publică în 1933 romanul său „Bruder, nimm die Brüder mit” (Frate, ia-ți cu tine frații). Aceste romane descriu consecințele războiului şi reformele agrare din acea vreme.

În proza din perioada interbelică se remarcă o influență a expresionismului, în special în operele lui Stefan von Hannenheim şi Heinrich Zillich. Cititorii saşi resping cărțile lor, care prezintă aceste tendințe noi, ca şi pe cele cu accente naturaliste şi realiste.

Un scriitor care a promovat valorile estetice prin articolele sale publicate în „Die Karpaten” este Adolf Meschendörfer. Opera sa prezintă profunde influențe din impresionismul şi realismul critic german. Primul său roman, „Lenore. Roman eines nach Siebenbürgen Verschlagenen” (Leonora. Romanul unui naufragiat în Transilvania) a fost publicat anonim în 1908 în revista „Die Karpaten”, iar în 1920 a fost tipărit cu numele autorului. Următoarele sale volume, respectiv, „Die Stadt im Osten” (Oraşul de la Răsărit), „Der Büffelbrunnen” (Fântâna bivolilor) şi antologia „Siebenbürgische Geschichten” (Poveşti transilvănene), au ca tematică problematica vieții din Transilvania cu aspecte din viața comunității germane care locuieşte în acest spațiu.

De remarcat este şi activitatea literară a lui Oskar Wittstock, respectiv prin romanele sale: „Der sechste Tag” (A şasea zi) şi „Das heimatmüde Geschlecht” (Generația dezamăgită de patrie). În „Generația dezamăgită de patrie" scriitorul transpune modul în care războiul a afectat oamenii din punct de vedere psihologic.

În perioada 1924-1939, se evidențiază Heinrich Zillich prin activitatea sa literară şi publicistică. Scriitorul a scos în evidență problematica interculturalității, cea a interferențelor culturale precum şi a fenomenului transferului cultural. El transpune în proza sa aspecte specifice ale vieții saşilor din Transilvania. Zillich subliniază receptarea 
reciprocă etnică şi interferențele culturale create de-a lungul secolelor din spațiul multietnic transilvănean.

Zillich a debutat printr-o narațiune în care accentuează menținerea valorilor transilvănene şi păstrarea identității etnice şi culturale. El a scris povestiri, nuvele şi romane, pe care le-a publicat în țară, dar şi în Germania. Aceste narațiuni sunt o adevărată cronică a perioadei interbelice în spațiul transilvănean în care se reflectă atât viața germanilor cât şi a celorlalte naționalități de aici. De menționat sunt nuvelele sale dramatice: „Der Urlaub” (Concediul) şi „Der baltische Graf” (Contele baltic). Narațiunile sale scot în evidență, nu numai latura națională, cât şi pe cea eroică a faptelor şi întâmplărilor relatate.

Zillich are şi o activitate publicistică foarte bogată; articolele sale accentuează ideea de identitate dublă a saşilor transilvăneni şi sunt imprimate în revista de literatură şi cultură „Klingsor”. El a fost un adevărat mediator cultural deoarece prin traducerea creațiilor literare ale unor autori români, maghiari şi evrei, a reuşit să îi popularizeze în spaţiul cultural german.

Un alt scriitor renumit este Erwin Wittstock. Acesta continuă în proza sa tradiția literaturii de expresie germană, dar aduce şi elemente noi, respectiv studiul psihologic al caracterelor şi invocarea configurațiilor simbolice ale elementelor etnografice. Proza sa denotă o muncă migăloasă de îmbinare a frazelor şi potrivire a cuvintelor încât opera finală pare perfectă. În operele sale, Erwin Wittstock a descris peisajul natal în care apar mulți dintre eroii povestirilor sale.

Temele predilecte ale nuvelelor sunt emigrarea saşilor în America şi criza psihologică care afectează oamenii în timpul Primului Război Mondial. Scriitorul însuşi a trăit drama războiului şi din propria experiență transpune în narațiunile sale faptul că războiul distruge valorile morale şi îl pune pe individ într-o situație în care nu mai are niciun reper moral. Intreaga sa operă denotă o viziune realist critică. Mare parte dintre nuvelele sale au însă, o notă optimistă care reiese din încrederea în biruința binelui asupra răului, în supremația valorilor morale.

Prin nuvelele sale, profund ancorate în realitatea transilvăneană, scriitorul a reuşit să abordeze în diferite ipostaze problemele majore cu care se confruntă omul în devenirea sa, comunitatea umană în ansamblul ei, fiind precursorul operelor scriitorilor de expresie germană din perioada postbelică.

În România postbelică, comunitatea germană trăieşte o dramă care marchează profund nu numai pe cei implicați direct, afectați de regimul comunist, ci şi pe membrii familiilor acestora.

Literații germani din a doua jumătate a secolului XX au reflectat în operele lor tragismul anilor postbelici. Ei descriu în proza lor, nu numai 
brutalitatea şi tragismul suferit de membrii comunităţii germane în lagărele sovietice, dar şi deportarea în Bărăgan.

Un scriitor care reflectă suferința germanilor din Transilvania şi din Banat este Eginald Norbert Schlattner. Cărțile sale au caracter autobiografic şi tratează viața comunității germane dintre anii 1943-1960: „Der geköpfte Hahn” (Cocoşul decapitat), „Rote Handschuhe” (Mănuşile roşii) și „Das Klavier im Nebel” (Pianul în ceață).

În mare parte, scriitorii de la sfârşitul secolului al XIX-lea şi până la jumătatea secolului al XX-lea, au transpus în operele lor descrieri despre locul natal, legătura sentimentală dintre om şi patrie, tradițiile, obiceiurile, cultura germană, istoria Transilvaniei şi au luptat pentru păstrarea identității etnice şi culturale a minorităţii germane

\section{Bibliografie}

Anger, Horst Schuller. (1994). Kontakt und Wirkung. Literarische Tendenzen in der siebenbürgischen Kulturzeitschrift Klingsor. București: Editura Kriterion.

Berceanu, Maria, Wagner Udo Peter, Wittstock, Joachim et al. (1992). Beiträge zur Geschichte der rumäniendeutschen Dichtung. Die rumäniendeutsche Literatur in den Jahren 1918-1944, Redigiert von Joachim Wittstock und Stefan Sienerth. Bucureşti: Editura Kriterion.

Csaki, Richard. (1916). Einleitung zu jenseits der Walder (Introducere la Dincolo de păduri). Sibiu: Krafft.

Göllner, Carl, Wagner Udo Peter, Wittstock, Joachim et al., (1979). Beiträge zur Geschichte der rumäniendeutschen Dichtung. Die Literatur der Siebenbürger Sachsen in den Jahren 1849-1918, Redigiert von Joachim Wittstock und Carl Göllner. București: Editura Kriterion.

Krasser, Harald. (1935). "Die deutsche Dichtung Siebenbürgens in unserer Zeit (Literatura germană din Transilvania în zilele noastre)”, Klingsor, an 12.

Palea, Lucia Larissa. (2006). "Particularitati ale nuvelei române de expresie germana," Anuarul Academiei Forțelor Terestre „Nicolae Balcescu” Sibiu, https://www.armyacademy.ro/biblioteca/ anuare/2006/

Orend, Misch. (1928). "Der magische Realismus" (Realismul magic), în Klingsor, an 5, 1928.

Roth, Hermann. (1919). Grundlegende Voraussetzungen für den Besuch der Bilderausstellung der Grete CsakiCopony (Premise esențiale pentru vizita expoziției Gretei Csaki-Copony). Sibiu: f.e.

Săcărea (Coldea), Elena Teodora Mihaela. (2019). "The Evolution of German Lyrics and Prose from Transylvania," in: Journal of Romanian Literary Studies, 16: 872876.

Schlattner, Eginald Norbert. (1998). Der geköpfte Hahn (Cocoşul decapitat), Viena: Editura Paul Zsolnay. Tradus în limba română şi publicată la Editura Humanitas din București, în anul 2001.

Schlattner, Eginald Norbert. (2000). Rote Handschuhe (Mănuşile roşii), Viena: Editura Paul Zsolnay. Bucureşti: Editura Humanitas, 2003. 
Schlattner, Eginald Norbert. (2005). Das Klavier im Nebel (Pianul din ceață), Viena: Editura Paul Zsolnay. În limba română a apărut la Editura Cartier din Chişinău, în noiembrie 2014.

Sperber, Alfred Margul. (1963). "Vonwort zu Gleichnisse der Landschaft, citat după Dieter Schlesak, Auf der Suche nach Liebe," Neue Literatur, an 14.

Wittstock, Erwin. (1957). Fiul vizitiului. Traducere de I. Cassian-Mătăsaru, Bucureşti: Editura de Stat pentru Literatură şi Artă.

Wittstock, Erwin. (1971). O excursie cu unchiul Flieha. Traducere de Emanoil Cerbu. București: Editura Kriterion.

Wittstock, Erwin. (1987). Judecata de apoi la Altbirk. Traducere de Beatrice Staicu. Postfață de Joachim Wittstock. Bucureşti: Editura Kriterion.

Wittstock, Erwin. (1999). Einkehr. Prosa aus Siebenbürgen. München: Verlag Südostdeutsches Kulturwerk. 